\title{
POTENSI KOMODITAS KOPI DALAM PEREKONOMIAN DAERAH DI KECAMATAN PANGALENGAN KABUPATEN BANDUNG
}

\author{
POTENTIALS OF COFFEE COMMODITY IN THE REGIONAL ECONOMY \\ IN PANGALENGAN SUB DISTRICT, BANDUNG DISTRICT
}

\author{
Dina Fithriyyah*1,2 ${ }^{*}$ Eliana Wulandari ${ }^{2}$, Tuhpawana P. Sendjaja ${ }^{2}$ \\ ${ }^{1}$ Direktorat Jenderal Perkebunan, Kementerian Pertanian \\ J1. Harsono RM No.3 Ragunan Pasar Minggu, Jakarta Selatan 12550 \\ ${ }^{2}$ Pascasarjana Fakultas Pertanian Universitas Padjajaran \\ Jl. Raya Bandung Sumedang KM.21 Jatinangor, Sumedang, Jawa Barat 45363 \\ *Email: dinafithriyyah@gmail.com
}

(Diterima 12-04-2020; Disetujui 15-06-2020)

\begin{abstract}
ABSTRAK
Kopi adalah satu diantara komoditas unggulan perkebunan yang mempunyai peran penting dalam pertumbuhan ekonomi Indonesia, salah satunya adalah sebagai penyumbang pendapatan negara. Peran strategis kopi dalam perekonomian Indonesia, dapat dilihat dari kontribusi subsektor tanaman perkebunan terhadap PDB Indonesia dimana kopi menjadi salah satu komoditas unggulannya. Kabupaten Bandung khususnya Kecamatan Pangalengan merupakan salah satu sentra kopi khususnya arabika di Jawa Barat. Komoditas kopi sebagai tanaman perkebunan memiliki peran besar dalam peningkatan PDRB Kabupaten Bandung. Tujuan penelitian ini untuk mengetahui sejauh mana potensi komoditas kopi berperan dalam pertumbuhan ekonomi di Kabupaten Bandung khususnya di wilayah Kecamatan Pangalengan. Penelitian ini menggunakan metode deskriptif kuantitatif, dengan sumber data time series produksi tanaman perkebunan periode tahun 2012-2016. Analisis yang digunakan adalah Location Quotient (LQ) dan Shift Share. Hasil penelitian ini menunjukkan bahwa komoditas kopi merupakan komoditas unggulan atau basis dari sektor perkebunan, baik di Kecamatan Pangalengan maupun di Kabupaten Bandung. Analisis shift share menunjukkan bahwa komoditas kopi mengalami pertumbuhan yang positif, baik di Kecamatan Pangalengan maupun di Kabupaten Bandung, meskipun secara agregat pertumbuhan produksi sektor perkebunan mengalami penurunan di Kabupaten Bandung.
\end{abstract}

Kata kunci: Kopi, Basis, Perkebunan, Bandung

\section{ABSTRACT}

Coffee is one of plantation commodities that plays an important role for Indonesian economy, in which of its benefits is for country income. The strategic role of coffee in Indonesian economy can be observed from contribution of the plantation sub-sector to Indonesia's Gross Domestic Product $(G D P)$, in which coffee is the main plantation commodity. Pangalengan Sub District, Bandung District is one of the arabica coffee centers in West Java. Coffee has a big role to increase Gross Regional Domestic Product (GRDP) in Bandung. This study aims to determine the potential of coffee commodity for economic growth in Bandung, especially in Pangalengan. This research used quantitative descriptive methods using time series data from the production of estate crops in the period of 2012-2016. The analysis used Location Quotient (LQ) and Shift Share. The results of this study indicate that coffee is the main plantation commodity in Pangalengan and Bandung. The shift share analysis shows that coffee has a positive growth both in Pangalengan and Bandung even though the whole production growth in plantation sectors decreased in Bandung.

Keywords: Coffee, Base, Plantation, Bandung 


\section{PENDAHULUAN}

Pertanian merupakan salah satu sektor yang memiliki peranan penting dan strategis dalam pembangunan regional dan nasional. Menurut Marlina (2014), sektor pertanian merupakan basis dan landasan perekonomian Indonesia, mengingat secara ekonomi kontribusi sektor pertanian terhadap perekonomian nasional relatif masih cukup besar. Berdasarkan laporan Badan Pusat Statistik (2019) menyebutkan bahwa pertumbuhan ekonomi di Indonesia tahun 2018 mencapai 5,17 persen dimana sumber pertumbuhan dari sektor pertanian, kehutanan dan perikanan sebesar $0,50 \%$.

Dilihat dari struktur Produk Domestik Bruto (PDB) Indonesia menurut lapangan usaha atas dasar harga berlaku pada tahun 2018, sektor Pertanian, Kehutanan dan Perikanan masih menjadi salah satu sektor yang mendominasi perekonomian Indonesia yaitu sebesar 12,81\% (Badan Pusat Statistik, 2019). Dari beberapa sub kategori, tanaman pangan dan tanaman perkebunan merupakan dua sub kategori yang memberikan kontribusi terbesar yaitu lebih dari $50 \%$ terhadap pembentukan PDB Lapangan Usaha
Pertanian, Kehutanan dan Perikanan (Badan Pusat Statistik, 2018).

Salah satu komoditas perkebunan yang mempunyai peran strategis bagi perekonomian Indonesia adalah kopi. Selain sebagai penyumbang devisa negara, perkebunan kopi berperan juga sebagai penyedia lapangan kerja, memelihara kelestarian lingkungan, serta sumber bahan baku bagi industri makanan dan minuman (Direktorat Jenderal Perkebunan, 2015). Komoditas ini diperkirakan menjadi salah satu sumber pendapatan utama tidak kurang dari 1,84 juta petani kopi yang sebagian besar mendiami kawasan perdesaan di wilayah-wilayah terpencil (Direktorat Jenderal Perkebunan, 2014). Sebagai salah satu komoditas unggulan perkebunan di Indonesia, dilihat dari luasan pengembangan, tanaman kopi menduduki peringkat 5 setelah kelapa sawit, kelapa, karet dan kakao. Luas perkebunan kopi di Indonesia sampai saat ini mencapai 1,24 juta hektar dengan persentase perkebunan rakyat (PR) sebesar 96\%, perkebunan besar milik negara $(\mathrm{PBN}) 2 \%$ dan perkebunan besar milik swasta (PBS) sebesar 2\% (Direktorat Jenderal Perkebunan, 2018). Hal tersebut menunjukkan bahwa peranan petani kopi dalam perekonomian 
nasional cukup penting, yang berarti bahwa keberhasilan perkopian Indonesia secara langsung dapat memperbaiki kesejahteraan petani (Direktorat Jenderal Perkebunan, 2014).

Sebagai salah satu komoditas unggulan perkebunan, peran strategis kopi dalam perekonomian Indonesia, dapat dilihat dari kontribusi sub sektor tanaman perkebunan terhadap PDB Indonesia. Selama kurun waktu tahun 2012-2016, persentase rata-rata kontribusi PDB sub sektor tanaman perkebunan terhadap sektor pertanian, kehutanan dan perikanan adalah sebesar 29,48\%. Sedangkan kontribusi PDB sub sektor tanaman perkebunan terhadap total PDB Indonesia menurut lapangan usaha dalam kurun waktu tahun 2012-2016 rata-rata sebesar $3,88 \%$ (BPS diolah, 2019).

Sebagai empat besar negara eksportir kopi dunia setelah Brazil, Kolombia dan Vietnam, pasar ekspor kopi Indonesia untuk kopi robusta ditujukan ke negara Jepang, Amerika, Amerika Latin, Afrika Selatan dan Eropa. Sementara segmen pasar kopi arabika Indonesia ditujukan ke negara Jerman dan Amerika (Badan Penelitian dan Pengembangan Pertanian, 2012). Badan Pusat Statistik (2018) menyatakan bahwa dalam kurun waktu 2010-2017, volume ekspor kopi cenderung berfluktuasi, berkisar antara 27,94\% sampai dengan $30,46 \%$. Volume ekspor kopi Indonesia tahun 2010 mencapai 433,6 ribu ton dengan total nilai sebesar US\$ 814,3 juta meningkat pada tahun 2017 menjadi 467,8 ribu ton senilai US\$ $1.187,16$ juta.

Selain sebagai penyumbang devisa, peran strategis kopi juga karena merupakan sektor yang menyerap tenaga kerja. Sebagian besar perkebunan kopi secara nasional dikelola oleh rakyat sehingga banyak masyarakat yang terlibat di dalamnya. Total perkebunan kopi rakyat (PR) mencapai 96,21\% dari keseluruhan perkebunan kopi di Indonesia yang diusahakan oleh sekitar 1.770.508 petani, sedangkan sisanya dikelola oleh PBN dan PBS. Tanaman kopi yang banyak diusahakan di Indonesia adalah jenis Robusta yaitu sekitar 73,67\%, sedangkan 26,33\% sisanya jenis kopi Arabika (Direktorat Jenderal Perkebunan, 2018).

Provinsi Jawa Barat merupakan salah satu penghasil kopi di Indonesia. Selain teh, kopi menjadi satu di antara komoditas perkebunan andalan di Jawa Barat. Data Badan Pusat Statistik Provinsi Jawa Barat menyebutkan bahwa dari segi luas pengembangan tanaman 
perkebunan di Jawa Barat, kopi berada di urutan kelima setelah kelapa, teh, karet dan cengkeh. Produksi kopi di Jawa Barat relatif meningkat setiap tahun. Data dari Dinas Perkebunan Provinsi Jawa Barat (2018) menyatakan bahwa lahan perkebunan kopi rakyat di Jawa Barat mencapai lebih dari 38 ribu ha. Kopi merupakan salah satu komoditas perkebunan andalan di Jawa Barat yang mempunyai peranan yang cukup strategis dalam perekonomian Provinsi Jawa Barat. Dalam kurun waktu tahun 20122016, rata-rata kontribusi subsektor tanaman perkebunan terhadap Produk Domestik Regional Bruto (PDRB) Provinsi Jawa Barat atas dasar harga konstan tahun 2010 sebesar $0,75 \%$. Sedangkan kontribusi sub sektor tanaman perkebunan terhadap sektor pertanian, kehutanan dan perikanan adalah sebesar 9,21 \% (BPS Provinsi Jawa Barat diolah).

Produksi kopi di Jawa Barat berkembang cukup baik. Data statistik menunjukkan bahwa pada tahun 2012, jumlah produksi kopi mencapai 15.567 ton dari total luas lahan 30.620 ha. Pengembangan kopi di Jawa Barat cenderung mempunyai tren yang meningkat dari segi luasan lahan dan produksi. Jumlah produksi kopi mengalami peningkatan pada tahun 2016 hingga mencapai 17.684 ton, dari total luas lahan 33.889 ha (Badan Pusat Statistik Provinsi Jawa Barat, 2017).

Salah satu sentra kopi di Jawa Barat terutama untuk jenis kopi arabika adalah Kabupaten Bandung. Sebagian besar wilayah Kabupaten Bandung merupakan pegunungan dengan ketinggian rata-rata di atas $2000 \mathrm{mdpl}$, beriklim tropis dengan curah hujan rata-rata adalah $6,55 \mathrm{~mm} /$ hari pada tahun 2016. Hal tersebut sesuai dengan persyaratan tumbuh tanaman kopi arabika (Ditjenbun, 2014). Kabupaten Bandung merupakan produsen kopi terbesar di Jawa Barat dengan luas areal dan produksi yang relatif meningkat dalam kurun waktu tahun 2012-2016. Pada tahun 2012, luas areal kopi di Kabupaten Bandung adalah 10.024 ha dengan produksi sebesar 26.168 ton. Tahun 2016, luas areal kopi bertambah menjadi 10.027 ha dengan produksi yang meningkat sebesar 27.625 ton (Badan Pusat Statistik Kabupaten Bandung, 2017).

Memiliki peran yang strategis, menjadi salah satu kekuatan ekonomi komoditas kopi di Provinsi Jawa Barat khususnya di Kabupaten Bandung. Strategisnya pengusahaan komoditas kopi bagi Kabupaten Bandung khususnya dan Provinsi Jawa Barat umumnya, 
dikarenakan peran kopi bagi orang banyak, selain membuka lapangan kerja yang berdampak pada perbaikan ekonomi masyarakat perdesaan hingga ke perkotaan, perkebunan kopi juga berkonstribusi pada aspek kelestarian lingkungan. Perakaran tanaman kopi yang kuat, menjadikan tanaman ini salah satu andalan dalam pelestarian hutan, pemulihan lahan kritis, penahan erosi dan banjir saat musim hujan, sumber cadangan air saat kemarau serta sumber oksigen (Balai Proteksi Tanaman Perkebunan Provinsi Jawa Barat, 2016). Dilihat dari aspek pertumbuhan ekonomi, komoditas kopi merupakan salah satu penyumbang PDRB Kabupaten Bandung dari sektor pertanian, kehutanan dan perikanan. Berdasarkan harga konstan tahun 2010, total PDRB Kabupaten Bandung pada tahun 2018 meningkat dibanding tahun 2017. Meningkatnya produksi di hampir seluruh lapangan usaha yang sudah bebas dari pengaruh inflasi sedikit banyak mempengaruhi peningkatan PDRB tersebut. Sebanyak 16 lapangan usaha dari 17 lapangan usaha yang ada mengalami pertumbuhan yang positif. Lapangan usaha pertanian, kehutanan, dan perikanan sendiri mengalami pertumbuhan positif sebesar 1,40 persen. Dalam kurun waktu tahun
2012-2016, kontribusi rata-rata lapangan usaha pertanian, kehutanan, dan perikanan terhadap PDRB Kabupaten Bandung atas dasar harga konstan tahun 2010 sebesar 7,93\%.

\section{Tercapainya}

pembangunan ekonomi di suatu daerah tidak terlepas dari adanya pertumbuhan ekonomi. Sama halnya dengan Kabupaten Bandung, tercapainya pembangunan ekonomi merupakan kontribusi dari pertumbuhan ekonomi sehingga diperlukan perencanaan pembangunan yang berdasar pada potensi sektoral. Oleh karena itu, diperlukan suatu analisis sektor unggulan Kabupaten Bandung agar pengembangan wilayah sesuai dengan potensi sektoralnya. Ditinjau dari nilai PDRB wilayah, sektor pertanian termasuk didalamnya adalah komoditas kopi sebagai tanaman perkebunan memiliki peran besar dalam peningkatan PDRB Kabupaten Bandung. Tujuan penelitian ini untuk mengetahui sejauh mana potensi komoditas kopi mempunyai peran dalam pertumbuhan ekonomi di Kabupaten Bandung, khususnya di wilayah Kecamatan Pangalengan. Dengan menggunakan analisis location quotient (LQ) dan shift share (SS) diharapkan dapat diketahui posisi 


\section{POTENSI KOMODITAS KOPI DALAM PEREKONOMIAN DAERAH \\ DI KECAMATAN PANGALENGAN KABUPATEN BANDUNG \\ Dina Fithriyyah, Eliana Wulandari, Tuhpawana P. Sendjaja}

komoditas kopi dalam pembangunan ekonomi di Kabupaten Bandung.

\section{METODE PENELITIAN}

Penelitian ini menggunakan metode deskriptif kuantitatif. Deskripsi yaitu menggambarkan secara faktual, akurat dan sistematis suatu perlakuan pada wilayah tertentu. Sedangkan metode kuantitatif digunakan untuk mengidentifikasi dan menganalisis potensi ekonomi suatu daerah dengan cara mengukur variabel-variabel yang terkait berdasarkan tingkat produksi tanaman perkebunan untuk mengungkap kecenderungan dan membuktikan secara matematis sederhana berbagai data yang bersifat kuantitatif.

Penelitian dilakukan di Kecamatan Pangalengan, Kabupaten Bandung dengan pertimbangan bahwa Kecamatan Pangalengan adalah sentra produksi kopi di Kabupaten Bandung. Data produksi kopi per kecamatan tahun 2012-2016 di Kabupaten Bandung dapat dilihat pada Tabel 1.

Tabel 1. Produksi Kopi per Kecamatan di Kabupaten Bandung Tahun 2012-2016

\begin{tabular}{llcccc}
\hline \multirow{2}{*}{ No } & \multirow{2}{*}{ Kecamatan } & \multicolumn{4}{c}{ Produksi (Ton) / Tahun } \\
\cline { 3 - 5 } & & $\mathbf{2 0 1 2}$ & $\mathbf{2 0 1 3}$ & $\mathbf{2 0 1 5}$ & $\mathbf{2 0 1 6}$ \\
\hline 1 & Pangalengan & $6.040,00$ & $6.342,00$ & $6.499,04$ & $6.523,20$ \\
2 & Paseh & $3.560,00$ & $3.453,20$ & - & $3.560,00$ \\
3 & Ibun & $2.864,00$ & $2.984,00$ & - & $3.580,80$ \\
4 & Kertasari & $2.763,36$ & $2.763,36$ & $2.831,76$ & $2.927,52$ \\
5 & Rancabali & $1.724,00$ & $1.724,00$ & $1,767,10$ & $1.767,10$ \\
6 & Kecamatan lainnya & $9.217,32$ & $9.283,84$ & $7.873,72$ & $9.266,49$ \\
\hline & Total & $\mathbf{2 6 . 1 6 8 , 6 8}$ & $\mathbf{2 6 . 5 5 0 , 4 0}$ & $\mathbf{1 8 . 9 7 1 , 6 2}$ & $\mathbf{2 7 . 6 2 5 , 1 1}$ \\
\hline
\end{tabular}

Sumber: Badan Pusat Statistik 2017 (diolah)

Dalam penelitian ini, data sekunder yaitu data produksi tanaman perkebunan periode tahun 2012-2016 dianalisis untuk menentukan komoditas perkebunan unggulan di Kecamatan Pangalengan dan Kabupaten Bandung dengan menggunakan analisis Location Quotient (LQ) dan Shift Share (SS).

Analisis LQ digunakan untuk mengetahui sejauh mana tingkat spesialisasi sektor-sektor ekonomi di suatu wilayah yang memanfaatkan sektor basis atau leading sector dengan menghitung perbandingan antara share output sektor i di suatu wilayah dengan share out sektor i di tingkat wilayah yang lebih atas. Menurut Tarigan (2005), salah satu aspek dari analisis LQ adalah sebagai salah satu indikator untuk menentukan sektor unggulan daerah.

Hendayana (2003) dalam Hidayat (2013) menyatakan bahwa nilai LQ dapat menunjukkan kemampuan suatu daerah dalam memproduksi suatu komoditas, 
apakah daerah tersebut hanya mampu memenuhi kebutuhan untuk daerah sendiri atau produksi surplus sehingga mempunyai potensi untuk memasok ke daerah lain, atau produksi kurang hingga perlu pasokan dari daerah lain. Teknik LQ dapat juga digunakan sebagai metode untuk menentukan komoditas unggulan khususnya dari segi penawaran (produksi atau populasi). Adapun rumus LQ adalah sebagai berikut:

$L Q=\frac{Y i j / Y j}{Y i / Y}$

Dimana, Yij adalah nilai produksi komoditi perkebunan pada tingkat wilayah yang lebih rendah, $\mathrm{Vj}$ adalah total nilai produksi komoditi perkebunan pada tingkat wilayah yang lebih rendah, Yi adalah nilai produksi komoditi perkebunan pada tingkat wilayah yang lebih atas, dan $\mathrm{Y}$ adalah total nilai produksi komoditi perkebunan pada tingkat wilayah yang lebih atas.

Jika nilai koefisien LQ $>1$ mempunyai arti komoditas perkebunan tersebut merupakan komoditas basis atau unggulan dan mempunyai prospek dikembangkan untuk pertumbuhan perekonomian daerah. Sedangkan nilai LQ $<1$ berarti komoditas perkebunan tersebut termasuk non basis dan hanya mampu untuk memenuhi kebutuhan daerah tersebut bahkan bisa kurang, sehingga perlu pengelolaan lebih lanjut agar subsektor atau komoditas ini bisa berkembang dan berkontribusi bagi perekonomian daerah (Tarigan, 2005).

Untuk menentukan kinerja atau produktivitas kerja perekonomian daerah dengan membandingkannya dengan daerah yang lebih besar (regional atau nasional) digunakan analisis Shift Share. Shift share merupakan suatu teknik untuk menghitung Pertumbuhan Nasional $(\mathrm{N})$, Bauran Industri (M), Keunggulan Kompetitif (C) sehingga diperoleh Dampak Nyata Pertumbuhan (D) dari suatu variabel wilayah selama kurun waktu (Hidayat, 2013).

Menurut Soepomo dalam jurnal Basuki dan Gayatri (2009) dalam Sapriadi dan Hasbiullah (2015), komponen-komponen dan rumus dari analisis shift share adalah:

$D_{i j}=N_{i j}+M_{i j}+C_{i j}$

$\mathrm{N}_{\mathrm{ij}}=\mathrm{E}_{\mathrm{ij}} \cdot \mathrm{r}_{\mathrm{n}}$

$M_{i j}=E_{i j}\left(r_{i n}-r_{n}\right)$

$\mathrm{C}_{\mathrm{ij}}=\mathrm{E}_{\mathrm{ij}}\left(\mathrm{r}_{\mathrm{ij}}-\mathrm{r}_{\mathrm{in}}\right)$

Dimana, i adalah sektor-sektor ekonomi yang diteliti; $\mathrm{j}$ adalah variabel wilayah/daerah yang diteliti variabel (Kecamatan Pangalengan; Kabupaten Bandung); $\mathrm{D}_{\mathrm{ij}}$ adalah perubahan sektor $\mathrm{i}$ di daerah j (tingkat wilayah yang lebih rendah); $\mathrm{N}_{\mathrm{ij}}$ adalah pertumbuhan sektor $\mathrm{i}$ 
di daerah $\mathrm{j}$ (tingkat wilayah yang lebih rendah); $\mathrm{M}_{\mathrm{ij}}$ adalah bauran industri sektor $\mathrm{i}$ di daeraj j (tingkat wilayah yang lebih rendah); $\quad \mathrm{C}_{\mathrm{ij}} \quad$ adalah keunggulan kompetitif sektor $\mathrm{i}$ di daerah $\mathrm{j}$ (tingkat wilayah yang lebih rendah); $\mathrm{E}_{\mathrm{ij}}$ adalah produksi sektor i di daerah $\mathrm{j}$ (tingkat wilayah yang lebih rendah); $r_{i j}$ adalah laju pertumbuhan sektor $\mathrm{i}$ di daerah $\mathrm{j}$ (tingkat wilayah yang lebih rendah); $r_{\text {in }}$ adalah laju pertumbuhan sektor $\mathrm{i}$ di daerah $\mathrm{n}$ (tingkat wilayah yang lebih atas); $r_{n}$ adalah laju pertumbuhan total sektor di daerah $\mathrm{n}$ (tingkat wilayah yang lebih atas).

\section{HASIL DAN PEMBAHASAN}

Perkembangan Luas Tanam dan Produksi Komoditas Perkebunan di

\section{Kecamatan Pangalengan, Kabupaten Bandung}

Daerah Pangalengan adalah salah satu kecamatan yang terletak di Kabupaten Bandung, Provinsi Jawa Barat berada pada dataran yang cukup tinggi. Letak geografis menjadikan daerah ini sentra perkebunan kopi terutama kopi arabika di Bandung. Selain kopi, tanaman perkebunan yang dikembangkan di Pangalengan adalah teh dan cengkeh. Komoditas perkebunan tidak banyak dikembangkan di kecamatan ini, karena mayoritas masyarakat menanam sayuran. Adapun perkembangan produksi dan luas areal tanaman perkebunan di Kecamatan Pangalengan disajikan pada Tabel 2.

Tabel 2. Produksi dan Luas Areal Tanaman Perkebunan di Kecamatan Pangalengan Tahun 20122016

\begin{tabular}{|c|c|c|c|c|c|c|c|c|c|c|}
\hline \multirow[b]{2}{*}{ Komoditas } & \multicolumn{2}{|c|}{2012} & \multicolumn{2}{|c|}{2013} & \multicolumn{2}{|c|}{2014} & \multicolumn{2}{|c|}{2015} & \multicolumn{2}{|c|}{2016} \\
\hline & $\begin{array}{l}\text { Produksi } \\
\text { (Ton) }\end{array}$ & $\begin{array}{c}\text { Luas } \\
\text { Areal } \\
\text { (Ha) }\end{array}$ & $\begin{array}{l}\text { Produksi } \\
\text { (Ton) }\end{array}$ & $\begin{array}{c}\text { Luas } \\
\text { Areal } \\
\text { (Ha) }\end{array}$ & $\begin{array}{l}\text { Produksi } \\
\text { (Ton) }\end{array}$ & $\begin{array}{c}\text { Luas } \\
\text { Areal } \\
\text { (Ha) }\end{array}$ & $\begin{array}{l}\text { Produksi } \\
\text { (Ton) }\end{array}$ & $\begin{array}{c}\text { Luas } \\
\text { Areal } \\
(\mathrm{Ha})\end{array}$ & $\begin{array}{l}\text { Produksi } \\
\text { (Ton) }\end{array}$ & $\begin{array}{c}\text { Luas } \\
\text { Areal } \\
\text { (Ha) }\end{array}$ \\
\hline Kopi & $13.106,60$ & $1.312,20$ & $11.313,84$ & $1.312,20$ & $10.993,66$ & $1.312,20$ & $10.993,66$ & $1.312,20$ & $14.680,20$ & $1.208,10$ \\
\hline Teh & $10.299,35$ & $6.650,99$ & $53.230,65$ & $6.650,99$ & $61.621,83$ & $6.650,99$ & $8.697,55$ & $6.650,99$ & $11.712,69$ & $6.010,99$ \\
\hline
\end{tabular}

Sumber: Badan Pusat Statistik 2017 (diolah)

Dilihat dari luas areal tanaman, komoditas kopi di Kecamatan Pangalengan menduduki posisi kedua setelah teh. Areal pengembangan komoditas kopi sebagian berada pada kawasan hutan Perhutani melalui pengelolaan bersama hutan masyarakat sehingga terbentuklah kelompokkelompok tani hutan (KTH), khususnya untuk komoditas kopi. Produksi kopi di Kecamatan Pangalengan antara tahun 2012-2016 rata-rata mencapai lebih dari 12.000 ton dan cenderung mengalami peningkatan. Kondisi cuaca yang baik 
sangat mempengaruhi tingkat produksi kopi.

Sama halnya dengan Kecamatan Pangalengan, untuk seluruh wilayah Kabupaten Bandung, komoditas perkebunan yang banyak diusahakan adalah kopi, teh, cengkeh dan sebagian kecil tembakau. Perkembangan produksi dan areal tanaman perkebunan di Kabupaten Bandung disajikan pada Tabel 3.

Tabel 3. Produksi dan Luas Areal Tanaman Perkebunan di Kabupaten Bandung Tahun 2012-2016

\begin{tabular}{|c|c|c|c|c|c|c|c|c|c|c|}
\hline \multirow[b]{2}{*}{$\begin{array}{c}\text { Komo- } \\
\text { ditas }\end{array}$} & \multicolumn{2}{|c|}{2012} & \multicolumn{2}{|c|}{2013} & \multicolumn{2}{|c|}{2014} & \multicolumn{2}{|c|}{2015} & \multicolumn{2}{|c|}{2016} \\
\hline & $\begin{array}{l}\text { Produksi } \\
\text { (Ton) }\end{array}$ & $\begin{array}{c}\text { Luas } \\
\text { Areal (Ha) }\end{array}$ & $\begin{array}{l}\text { Produksi } \\
\text { (Ton) }\end{array}$ & $\begin{array}{c}\text { Luas } \\
\text { Areal (Ha) }\end{array}$ & $\begin{array}{l}\text { Produksi } \\
\text { (Ton) }\end{array}$ & $\begin{array}{c}\text { Luas } \\
\text { Areal (Ha) }\end{array}$ & $\begin{array}{l}\text { Produksi } \\
\text { (Ton) }\end{array}$ & $\begin{array}{c}\text { Luas } \\
\text { Areal (Ha) }\end{array}$ & $\begin{array}{l}\text { Produksi } \\
\text { (Ton) }\end{array}$ & $\begin{array}{c}\text { Luas } \\
\text { Areal (Ha) }\end{array}$ \\
\hline Kopi & $26.168,68$ & $10.024,00$ & $26.550,40$ & $10.013,00$ & $10.600,19$ & $10.423,00$ & $18.971,62$ & $6.818,00$ & $27.625,11$ & $10.027,00$ \\
\hline Teh & $33.948,48$ & $19.623,99$ & $38.599,00$ & $18.928,79$ & $35.842,00$ & $19.190,00$ & $23.808,82$ & $17.750,39$ & $31.495,22$ & $19.003,91$ \\
\hline Tembakau & $6.890,31$ & $1.545,00$ & $8.392,05$ & $1.848,00$ & $5.898,90$ & $1.524,00$ & $3.405,75$ & 767,00 & $6.810,65$ & $1.524,00$ \\
\hline Cengkeh & 463,81 & 942,00 & 440,19 & 962,00 & 209,00 & 118,00 & 468,63 & 951,00 & 535,29 & $1.024,00$ \\
\hline
\end{tabular}

Sumber: Badan Pusat Statistik 2017 (diolah)

\section{Analisis Identifikasi Komoditas Unggulan/Basis dan Laju Pertumbuhan Sektor Perkebunan di Kecamatan Pangalengan Kabupaten Bandung}

\section{Analisis Location Quotient (LQ)}

Dalam penentuan sektor yang potensial untuk dikembangkan, nilai LQ dapat digunakan sebagai petunjuk untuk dijadikan dasar menentukannya. Hal ini dikarenakan suatu sektor dikatakan potensial jika produksi sektor tersebut mampu memenuhi kebutuhan di dalam daerah sendiri dan dapat mensupplai kebutuhan daerah lain.

Data yang dianalisis adalah data produksi dari 4 komoditas perkebunan yang dikembangkan di Kabupaten Bandung. Nilai LQ komoditas perkebunan Kecamatan Pangalengan periode tahun 2012-2016 dapat dilihat pada Tabel 4.

Tabel 4. Hasil Analisis Location Quotient (LQ) Komoditas Perkebunan Kecamatan Pangalengan Tahun 2012-2016

\begin{tabular}{clccccccc}
\hline \multirow{2}{*}{ No. } & \multirow{2}{*}{ Sektor Perkebunan } & \multicolumn{9}{c}{ Nilai LQ } & \multirow{2}{*}{ Rata-rata } & \multirow{2}{*}{ Keterangan } \\
\cline { 3 - 6 } & & $\mathbf{2 0 1 2}$ & $\mathbf{2 0 1 3}$ & $\mathbf{2 0 1 4}$ & $\mathbf{2 0 1 5}$ & $\mathbf{2 0 1 6}$ & & Basis \\
\hline 1. & Kopi & 1,44 & 0,49 & 0,75 & 1,37 & 1,34 & 1,08 & Basis \\
2. & Teh & 0,87 & 1,58 & 1,24 & 0,87 & 0,94 & 1,10 & Non Basis \\
3. & Tembakau & 0,00 & 0,00 & 0,00 & 0,00 & 0,00 & 0,00 & Non Basis \\
4. & Cengkeh & 0,07 & 0,03 & 0,04 & 0,06 & 0,06 & 0,05 &
\end{tabular}

Sumber: Analisis data primer (2019) 
Dari tabel hasil analisis LQ di atas dapat dilihat bahwa pada periode tahun 2012-2016, komoditas kopi dan teh mempunyai nilai LQ rata-rata di atas 1 ( $>1$ ). Hasil ini menunjukkan bahwa kopi dan teh merupakan komoditas basis atau unggulan. Pengembangan kopi dan teh mempunyai prospek yang bagus dalam rangka peningkatan perekonomian daerah khususnya di wilayah Kecamatan Pangalengan.

Tabel 5. Hasil Analisis Location Quotient (LQ) Komoditas Perkebunan Kabupaten Bandung Tahun 2012-2016

\begin{tabular}{clrrrrrrl}
\hline \multirow{2}{*}{ No } & Sektor & \multicolumn{9}{c}{ Nilai LQ } & \multirow{2}{*}{ Rata-rata } & \multirow{2}{*}{ Keterangan } \\
\cline { 3 - 7 } & \multicolumn{1}{c}{ Perkebunan } & $\mathbf{2 0 1 2}$ & $\mathbf{2 0 1 3}$ & $\mathbf{2 0 1 4}$ & $\mathbf{2 0 1 5}$ & $\mathbf{2 0 1 6}$ & & Basis \\
\hline 1. & Kopi & 1,17 & 1,10 & 1,02 & 1,33 & 1,28 & 1,18 & Basis \\
2. & Teh & 0,93 & 0,92 & 1,11 & 0,98 & 1,06 & 1,00 & Basis \\
3. & Tembakau & 2,15 & 2,56 & 0,25 & 1,33 & 1,50 & 1,36 & Non Basis \\
4. & Cengkeh & 0,05 & 0,05 & 0,10 & 0,06 & 0,06 & 0,06 &
\end{tabular}

Sumber: Analisis Data Primer (2019)

Hasil analisis LQ komoditas perkebunan di wilayah Kabupaten Bandung, seperti dapat dilihat pada Tabel 5, menunjukkan bahwa komoditas kopi, teh dan tembakau mempunyai nilai LQ rata-rata di atas 1, yaitu masing-masing 1,18; 1,00; dan 1,36. Hasil tersebut menunjukkan bahwa komoditas kopi, teh dan tembakau merupakan komoditas unggulan dan menjadi basis perekonomian di Kabupaten Bandung.

Kopi menjadi salah satu komoditas perkebunan yang sangat prospek dikembangkan untuk meningkatkan perekonomian di Kabupaten Bandung selain teh dan tembakau. Kopi yang dihasilkan di Kabupaten Bandung sebagian besar adalah jenis kopi arabika, seperti terlihat pada Tabel 6 .
Tabel 6. Produksi dan Luas Lahan Kopi Arabika dan Robusta di Kabupaten Bandung Tahun 2018

\begin{tabular}{cccc}
\hline No. & Kopi & $\begin{array}{c}\text { Luas } \\
\text { Lahan (ha) }\end{array}$ & $\begin{array}{c}\text { Produksi } \\
\text { (ton) }\end{array}$ \\
\hline 1. & Arabika & 11.029 & 6.607 \\
2. & Robusta & 150 & 135 \\
\hline
\end{tabular}

Sumber: Dinas Perkebunan Provinsi Jawa Barat (2019)

Letak geografis menjadi keuntungan tersendiri sehingga kopi arabika berkembang cukup bagus di Kabupaten Bandung. Apalagi, pertumbuhan kedai kopi dan kafe memberi pengaruh positif bagi bisnis kopi, disamping ikut juga dalam menggerakkan ekonomi masyarakat.

\section{Analisis Shift Share}

Analisis Shift Share digunakan untuk mengetahui proses pertumbuhan ekonomi wilayah i dikaitkan dengan perekonomian daerah yang menjadi 
referensi. Dalam penelitian ini analisis Shift Share bertujuan untuk menjelaskan pengaruh komoditas subsektor perkebunan pada wilayah yang lebih tinggi (Provinsi Jawa Barat; Kabupaten Bandung) terhadap komoditas sub sektor perkebunan daerah (Kabupaten Bandung; Kecamatan Pangalengan). Pengaruh komponen pertumbuhan produksi (dalam ton) di Provinsi Jawa Barat dan/atau Kabupaten Bandung $\left(\mathrm{N}_{\mathrm{ij}}\right)$ menunjukkan seberapa besar pertumbuhan produksi komoditas tanaman perkebunan di provinsi dan/atau kabupaten berpengaruh (positif atau negatif) terhadap pertumbuhan produksi komoditas tanaman perkebunan di Kabupaten Bandung dan/atau Kecamatan Pangalengan.

Pengaruh bauran industri provinsi Jawa Barat dan/atau Kabupaten Bandung
$\left(\mathrm{M}_{\mathrm{ij}}\right)$, menunjukkan besarnya pengaruh laju pertumbuhan produksi komoditas perkebunan di Provinsi Jawa Barat dan/atau Kabupaten Bandung sektor i $\left(r_{\text {in }}\right)$ dan total laju pertumbuhan produksi komoditas perkebunan di Provinsi Jawa Barat dan/atau Kabupaten Bandung $\left(\mathrm{r}_{\mathrm{n}}\right)$ terhadap pertumbuhan produksi sektor $\mathrm{i}$ di Kabupaten Bandung dan/atau Kecamatan Pangalengan. Pengaruh laju pertumbuhan produksi komoditas perkebunan sektor i $\left(\mathrm{r}_{\mathrm{ij}}\right)$ di Kabupaten Bandung dan/atau Kecamatan Pangalengan dengan total laju pertumbuhan produksi komoditas perkebunan sektor i Provinsi Jawa Barat dan/atau Kabupaten Bandung $\left(\mathrm{r}_{\text {in }}\right)$ ditunjukkan oleh komponen keunggulan kompetitif $\left(\mathrm{C}_{\mathrm{ij}}\right)$. Perhitungan shift share dapat dilihat pada Tabel 7 dan 8 .

Tabel 7. Hasil Analisis Shift Share Komoditas Perkebunan Kecamatan Pangalengan Tahun 2012-2016 (ton)

\begin{tabular}{|c|c|c|c|c|c|c|c|c|}
\hline \multirow[b]{2}{*}{ No } & \multirow[b]{2}{*}{$\begin{array}{c}\text { Sektor } \\
\text { Perkebunan }\end{array}$} & \multirow[b]{2}{*}{ rij } & \multirow[b]{2}{*}{ rin } & \multirow[b]{2}{*}{ rn } & \multicolumn{3}{|c|}{ Komponen } & \multirow{2}{*}{$\begin{array}{c}\text { Dampak Nyata } \\
\text { Pertumbuhan } \\
\left(D_{\mathrm{ij}}\right)\end{array}$} \\
\hline & & & & & $\begin{array}{l}\text { Pertumbuhan } \\
\text { Nasional }\left(\mathbf{N}_{\mathrm{ij}}\right)\end{array}$ & $\begin{array}{c}\text { Bauran } \\
\text { Industri }\left(\mathbf{M}_{\mathrm{ij}}\right)\end{array}$ & $\begin{array}{l}\text { Pertumbuhan } \\
\text { Nasional }\left(\mathbf{N}_{\mathrm{ij}}\right)\end{array}$ & \\
\hline 1 & Kopi & 0,12 & 0,06 & $-0,01$ & $-181,98$ & 861,95 & 787,92 & $1.467,88$ \\
\hline 2 & Teh & 0,14 & $-0,07$ & $-0,01$ & $-433,64$ & $-1.670,15$ & $6.098,77$ & $3.994,98$ \\
\hline 3 & Tembakau & 0,00 & $-0,01$ & $-0,01$ & 0,00 & 0,00 & 0,00 & 0,00 \\
\hline 4 & Cengkeh & 0,00 & 0,15 & $-0,01$ & $-0,18$ & 2,03 & $-1,85$ & 0,00 \\
\hline & Total & 0,26 & 0,13 & $-0,06$ & $-615,80$ & $-806,17$ & $6.884,84$ & $5.462,86$ \\
\hline
\end{tabular}

Sumber: Analisis data primer (2019)

Hasil analisis Shift Share pada Tabel 7 menunjukkan bahwa selama tahun 2012-2016, produksi sektor tanaman perkebunan mengalami perkembangan atau pertumbuhan yang positif sebesar 5.462,86 ton. Pertumbuhan tersebut merupakan kontribusi dari peningkatan produksi 
komoditas kopi dan teh dengan nilai pertumbuhan masing-masing $1.467,88$ ton dan 3.994,98 ton. Ketiga komponen yaitu komponen pertumbuhan nasional $\left(\mathrm{N}_{\mathrm{ij}}\right)$, komponen bauran industri $\left(\mathrm{M}_{\mathrm{ij}}\right)$, dan komponen keunggulan kompetitif $\left(\mathrm{C}_{\mathrm{ij}}\right)$ mempengaruhi perkembangan tersebut.

$$
\text { Perhitungan komponen }
$$
pertumbuhan nasional (Nij) menunjukkan bahwa pertumbuhan produksi komoditas perkebunan Kabupaten Bandung telah mempengaruhi pertumbuhan produksi komoditas perkebunan Kecamatan Pangalengan sebesar $-615,80$ ton. Nilai negatif komponen pertumbuhan nasional $\left(\mathrm{N}_{\mathrm{ij}}\right)$ baik pada total maupun masingmasing komoditas perkebunan berarti bahwa produksi komoditas perkebunan Kecamatan Pangalengan tidak bergantung pada besarnya produksi komoditas perkebunan Kabupaten Bandung.

Tingkat perubahan perekonomian daerah sebagai dampak dari adanya bauran industri ditunjukkan oleh komponen bauran industri $\left(\mathrm{M}_{\mathrm{ij}}\right)$. Dari Tabel 7 di atas menunjukkan bahwa bauran industri memberikan pengaruh yang negatif bagi perkembangan produksi komoditas perkebunan, yaitu sebesar $-806,17$ ton. Pengaruh komponen bauran industri $\left(\mathrm{M}_{\mathrm{ij}}\right)$ yang bernilai negatif memperlihatkan bahwa laju pertumbuhan produksi komoditas sub sektor perkebunan di Kecamatan Pangalengan mengalami penurunan. Komoditas yang mengalami penurunan laju pertumbuhan adalah teh sebesar 1.670,15 ton, sedangkan komoditas kopi dan cengkeh mengalami peningkatan laju pertumbuhan produksi masing-masing sebesar 861,95 ton dan 2,03 ton. Nilai negatif mengindikasikan juga bahwa sektor perkebunan Kecamatan Pangalengan cenderung mengarah pada laju pertumbuhan produksi yang relatif lambat, pengaruh efek bauran industri terhadap pertumbuhan produksi komoditas perkebunan Kecamatan Pangalengan masih sangat kecil bahkan minus.

Nilai $\mathrm{C}_{\mathrm{ij}}$ (komponen keunggulan kompetitif) pada Tabel 7 adalah sebesar $6.884,84$ ton. Nilai ini mengindikasikan bahwa keunggulan kompetitif yang dihasilkan akan meningkatkan produksi tanaman perkebunan Kecamatan Pangalengan. Komoditas yang memiliki keunggulan kompetitif adalah kopi dan teh dengan masing-masing nilainya sebesar 787,92 ton dan 6098,77 ton, sedangkan tembakau dan cengkeh tidak memiliki keunggulan kompetitif di 
Kecamatan Pangalengan. Kopi dan teh merupakan komoditas perkebunan yang mengalami pertumbuhan lebih cepat dibandingkan komoditas perkebunan lain di tingkat Kabupaten Bandung. Hal tersebut mengisyaratkan bahwa pengembangan kopi dan teh berpotensi untuk memacu pertumbuhan perekonomian di Kecamatan Pangalengan.
Jika pada Kecamatan Pangalengan kopi dan teh dan merupakan komoditas yang memiliki keunggulan, berbeda dengan di Kabupaten Bandung, teh tidak memiliki keunggulan kompetitif di tingkat Kabupaten Bandung, Hasil analisis Shift Share komoditas perkebunan Kabupaten Bandung dapat dlihat pada Tabel 8 .

Tabel 8. Hasil Analisis Shift Share Komoditas Perkebunan Kabupaten Bandung Tahun 2012-2016 (ton)

\begin{tabular}{|c|c|c|c|c|c|c|c|c|}
\hline \multirow[b]{2}{*}{ No. } & \multirow{2}{*}{$\begin{array}{c}\text { Sektor } \\
\text { Perkebunan }\end{array}$} & \multirow[b]{2}{*}{ rij } & \multirow[b]{2}{*}{ rin } & \multirow[b]{2}{*}{ rn } & \multicolumn{3}{|c|}{ Komponen } & \multirow{2}{*}{$\begin{array}{c}\text { Dampak Nyata } \\
\text { Pertumbuhan } \\
\left(D_{\mathrm{ij}}\right)\end{array}$} \\
\hline & & & & & $\begin{array}{l}\text { Pertumbuhan } \\
\text { Nasional }\left(\mathrm{N}_{\mathrm{ij}}\right)\end{array}$ & $\begin{array}{c}\text { Bauran } \\
\text { Industri }\left(\mathbf{M}_{\mathrm{ij}}\right)\end{array}$ & $\begin{array}{c}\text { Keunggulan } \\
\text { Kompetitif }\left(C_{i j}\right)\end{array}$ & \\
\hline 1. & Kopi & 0,13 & 0,14 & $-0,07$ & $-454,03$ & $1.387,48$ & $-27,82$ & 905,62 \\
\hline 2. & Teh & $-0,07$ & $-0,10$ & $-0,07$ & $-2.244,83$ & $-1.265,60$ & 972,11 & $-2.538,32$ \\
\hline 3. & Tembakau & $-0,80$ & $-0,06$ & $-0,07$ & $-273,14$ & 6,26 & $-3.050,13$ & $-3.317,01$ \\
\hline & Cengkeh & 0,16 & 0,08 & $-0,07$ & $-9,18$ & 19,74 & 10,97 & 21,54 \\
\hline & Total & $-0,59$ & 0,04 & $-0,26$ & $-2.981,17$ & 147,88 & $-2.094,87$ & $-4.928,16$ \\
\hline
\end{tabular}

Sumber: Analisis data primer (2019)

Pada Tabel 8, hasil analisis Shift Share memperlihatkan bahwa selama tahun 2012-2016, komoditas perkebunan di Kabupaten Bandung mengalami perkembangan atau pertumbuhan yang negatif sebesar 4.928,16 ton. Nilai negatif yang dihasilkan mengindikasikan bahwa produksi komoditas perkebunan mengalami penurunan yang cukup besar yaitu pada komoditas teh dan tembakau.

$$
\text { Perhitungan komponen }
$$

pertumbuhan nasional $\left(\mathrm{N}_{\mathrm{ij}}\right)$ menunjukkan bahwa pertumbuhan produksi komoditas perkebunan Provinsi Jawa Barat telah mempengaruhi pertumbuhan produksi komoditas perkebunan Kabupaten Bandung sebesar $-2.981,17$ ton. Nilai negatif komponen pertumbuhan nasional $\left(\mathrm{N}_{\mathrm{ij}}\right)$ baik pada total maupun masingmasing komoditas perkebunan menunjukkan bahwa produksi komoditas perkebunan Kabupaten Bandung tidak bergantung pada besarnya produksi komoditas perkebunan Provinsi Jawa Barat.

Hasil analisis $\mathrm{M}_{\mathrm{ij}}$ menunjukkan bahwa bauran industri memberikan pengaruh yang positif bagi 
perkembangan produksi komoditas perkebunan, yaitu sebesar 147,88 ton. Hal ini menunjukkan adanya peningkatan laju pertumbuhan produksi komoditas perkebunan di Kabupaten Bandung. Komoditas kopi, tembakau dan cengkeh mengalami peningkatan laju pertumbuhan masing-masing sebesar 1.387,48 ton; 6,26 ton dan 19,74 ton, sedangkan komoditas teh mengalami penurunan laju pertumbuhan produksi sebesar 1.265,60 ton.

Nilai $\mathrm{C}_{\mathrm{ij}}$ (komponen keunggulan kompetitif) pada tabel 6 adalah sebesar $4.928,16$ ton. Hal ini menunjukkan keunggulan kompetitif yang dihasilkan tidak berpengaruh terhadap peningkatan produksi komoditas perkebunan di Kabupaten Bandung. Komoditas yang memiliki keunggulan kompetitif adalah kopi dan cengkeh dengan masing-masing nilainya sebesar 905,62 ton dan 21,54 ton sedangkan teh dan tembakau tidak memiliki keunggulan kompetitif di Kabupaten Bandung. Kopi dan cengkeh merupakan komoditas perkebunan yang mengalami pertumbuhan lebih cepat daripada komoditas perkebunan yang lain di Provinsi Jawa Barat, dan berpotensi untuk dikembangkan untuk mempercepat pertumbuhan perekonomian di Kabupaten Bandung.

\section{KESIMPULAN DAN SARAN}

Hasil analisis LQ menunjukkan bahwa komoditas kopi mempunyai peran dalam perekonomian daerah dimana menjadi sektor unggulan atau basis baik di tingkat Kecamatan Pangalengan maupun Kabupaten Bandung. Hasil analisis shift share menunjukkan pertumbuhan produksi komoditas perkebunan termasuk kopi di Kecamatan Pangalengan mengalami pertumbuhan yang positif, sedangkan di tingkat Kabupaten Bandung, pertumbuhan produksi tanaman perkebunan mengalami pertumbuhan yang negatif atau turun meskipun untuk komoditas kopi pertumbuhan produksi mengalami peningkatan.

Komoditas kopi menjadi sektor unggulan atau basis dan mengalami pertumbuhan yang positif baik di Kecamatan Pangalengan maupun di Kabupaten Bandung. Hal ini dapat menjadi pertimbangan pemerintah daerah dalam penentuan arah pengembangan sub sektor atau komoditas perkebunan ke depan dalam rangka memperkuat perekonomian daerah baik di tingkat Kecamatan Pangalengan, Kabupaten Bandung maupun Provinsi Jawa Barat. 


\section{DAFTAR PUSTAKA}

Arsyad, Lincolin. (2005). Pengantar Perencanaan Pembangunan Ekonomi Daerah Edisi Kedua. BPFE. Yogyakarta.

Badan Pusat Statistik (2016). Produk Domestik Bruto Indonesia Triwulanan 2012-2016. Badan Pusat Statistik. Jakarta.

Badan Pusat Statistik. (2017). Produk Domestik Bruto Indonesia Triwulanan 2013-2017. Badan Pusat Statistik. Jakarta.

Badan Pusat Statistik. (2018). Produk Domestik Bruto Indonesia Triwulanan 2014-2018. Badan Pusat Statistik. Jakarta.

Badan Pusat Statistik. (2019). Pertumbuhan Ekonomi Indonesia Triwulan IV-2018. Berita Resmi Statistik, No. 15/02/Th.XXII.

Badan Pusat Statistik Provinsi Jawa Barat. (2019). Produk Domestik Regional Bruto Provinsi Jawa Barat Menurut Lapangan Usaha 2014 - 2018. Badan Pusat Statistik Provinsi Jawa Barat. Bandung.

Direktorat Jenderal Perkebunan. (2014). Peraturan Menteri Pertanian Nomor 49/Permentan/OT.140/ 4/2014 Pedoman Teknis Budidaya Kopi Yang Baik (Good Agriculture Practise/GAP on Coffee). Direktorat Jenderal Perkebunan Kementerian Pertanian. Jakarta.
Dinas Perkebunan Provinsi Jawa Barat. (2018). Statistik Perkebunan Jawa Barat Angka Sementara 2018. Dinas Perkebunan Provinsi Jawa Barat. Bandung.

Hidayat, R. (2013). Analisis Komoditas Unggulan Sub Sektor Perkebunan di Kabupaten Bengkayang Provinsi Kalimantan Barat. Jurnal Social Economic of Agriculture, Volume 2, Nomor 1.

Marlina, L. (2014). Analisis Ekonomi Kopi Rakyat dan Peranannya Terhadap Perekonomian Wilayah Kabupaten Lampung Barat Provinsi Lampung. Tesis

Novitasari, R, Dedi, H, dan Cecep P. (2015). Analisis Kinerja Sektor Pertanian dalam Perekonomian Wilayah di Kota Banjar. Jurnal Ilmiah Mahasiswa AGROINFO GALUH, 2(1): 41-48.

Sapriadi dan Hasbiullah. (2015). Analisis Penentuan Sektor Unggulan Perekonomian Kabupaten Bulukumba. Jurnal Iqtisaduna, 1(1): 71-86.

Tarigan, R. (2005). Perencanaan Pembangunan Wilayah. Bumi Aksara. Jakarta. 